\title{
Univariate associations between housing, management, and facility design factors and the prevalence of lameness lesions in fourteen small-scale dairy farms in Northeastern Algeria
}

\author{
Zoubida Dendani-Chadi ${ }^{1}$, Khelaf Saidani ${ }^{2}$, Loubna Dib ${ }^{1}$, Fayçal Zeroual ${ }^{1}$, Faouzi Sammar ${ }^{3}$ and Ahmed Benakhla ${ }^{1}$
}

1. Department of Veterinary Medicine, Faculty of Natural Science and Life, University of Chadli Bendjedid, P.O. Box 73 El Tarf, 36000, Algeria; 2. Department of Veterinary Medicine, Saad Dahlab University P.O. Box 270 Blida, 09000, Algeria;

3. Department of Agronomy, Faculty of Natural Science and Life, University of Chadli Bendjedid, P.O. Box 73 El Tarf, 36000 , Algeria.

Corresponding author: Zoubida Dendani-Chadi, e-mail: z.dendani@hotmail.fr

Co-authors: KS: kamel_khelaf@yahoo.fr, LD: dib_loubna_dz@yahoo.fr, FZ: fayveto@gmail.com, FS: moho23dz@yahoo.com, AB: benakhlaahmed@gmail.com

Received: 04-11-2019, Accepted: 18-02-2020, Published online: 27-03-2020

doi: www.doi.org/10.14202/vetworld.2020.570-578 How to cite this article: Dendani-Chadi Z, Saidani K, Dib L, Zeroual F, Sammar F, Benakhla A (2020) Univariate associations between housing, management, and facility design factors and the prevalence of lameness lesions in fourteen small-scale dairy farms in Northeastern Algeria, Veterinary World, $13(3)$ : 570-578.

\begin{abstract}
Background and Aim: This cross-sectional study aimed to analyze the associations between different types of housing, management, and facilities on the prevalence of lame, causing lesions in smallholder dairy farms in Algeria.

Materials and Methods: The on-site investigation took place between December 2012 and May 2015. All cows were locomotion scored on a four-point scale, and foot lesions causing lame were diagnosed and recorded. Factors related to the farm and the cows' conditions were also assessed. The association between the possible risk factors and lame lesions was assessed using univariate analysis.

Results: Of the 349 cows evaluated, 13\% were lame (lameness score $\geq 2$ ), with higher lameness values recorded for the hind feet than for the forefeet. Cows without lameness were classified as healthy. The two most frequent lesion diagnoses observed in lame cows were interdigital dermatitis/heel horn erosion (ID/HE; 39\%) and interdigital phlegmon (IP; 35\%), followed by traumatic lesions (T; 11\%), digital dermatitis (DD; 8.7\%), and laminitis-related diseases (L; 6.5\%). The risk of being lame was increased in large herds with cows of the Holstein breed, and those in the third parity and above. Tie housing, concrete floor, concentrate feeding, zero-grazing, and the use of foot trimming occasionally were associated with increased risk for the presence of lame lesions. The region and footbathing frequency had no association with the prevalence of lame lesions $(\mathrm{p} \geq 0.05)$.
\end{abstract}

Conclusion: These results have important implications; they indicate that several aspects of housing, management, and facility design are common protective factors for the prevalence of lame lesions. These factors should be maintained correctly to not only reduce the number of lame cows in these herds but also decrease the direct and indirect costs associated with cases of lameness.

Keywords: Algeria, housing, lame cows, lesions, management, pasture.

\section{Introduction}

In smallholder dairy systems, which dominate our agriculture, Algerian dairy cattle population is estimated at 2 million, with estimated milk production of 3 billion liters [1]. Milk production systems can be broadly categorized into urban, peri-urban and rural, and are located in the north of the country. This area accounts for most of the dairy cow population (60\%), forage area $(60.9 \%)$, and domestic raw milk production $(63 \%)$. The rest, $26 \%$, occupies the regions with agropastoral vocations and semi-arid and arid climate, and $14 \%$ are located in the Saharan region with desert

Copyright: Dendani-Chadi, et al. Open Access. This article is distributed under the terms of the Creative Commons Attribution 4.0 International License (http://creativecommons.org/licenses/ by/4.0/), which permits unrestricted use, distribution, and reproduction in any medium, provided you give appropriate credit to the original author(s) and the source, provide a link to the Creative Commons license, and indicate if changes were made. The Creative Commons Public Domain Dedication waiver (http:// creativecommons.org/publicdomain/zero/1.0/) applies to the data made available in this article, unless otherwise stated. climate [2]. The Brown Atlas is the dominant indigenous breeds in the Northeast of Algeria; reared under the traditional extensive system, and characterized by limited productivity $(<1000 \mathrm{~kg} / \mathrm{cow}$ and per lactation) [1]. Their feeding depends largely on unimproved natural pasture, with seasonal supplementation [3]. Imported breeds mainly black and white Friesians, Holstein, and Montbéliard, and various crosses are reared either under an intensive or semi-intensive system. They produce $<4000 \mathrm{~kg} / \mathrm{cow}$ and per lactation on average, and are mainly concentrated in areas, generally with high irrigation potential, around urban agglomerations [1]. The herd sizes kept under these systems vary between 10 and 20 cows in extensive, 50 cows on average in the intensive and semi-intensive system. The semi-intensive system is practiced in areas of greater land availability and keeps cows on pasture during spring, but pasture is not the main source of feed; cows are housed indoors for a large proportion of the day, receiving silage, and 
concentrate supplementation. Intensive farming system is essentially "landless," since the animals are housed and fed. Farmers bring and provide water and chopped or cut grass to their cattle and animals are milked in automatic milking parlors.

The need to increase milk production in Algeria is a necessity, as the country depends largely on imports to fulfill the domestic demand for milk and dairy products. According to Kaouche-Adjlane et al. [1], $60 \%$ of milk requirements are imported, which costs approximately 769 million dollars/year. Such options have had important consequences on the whole organization of the dairy chains, and on the development of local production and collection of raw milk $[1,3]$. This inadequate cattle productivity is constrained by several factors such as problems of adaptation of imported breeds, low genetic potential of native livestock, water stress, lack of fodder production, costs of commercial feed, poor access to breeding, and poor herd-health management practice $[1,3]$. All these factors predisposed the cows to diseases and other stressful conditions. Lameness in cattle is one of the main causes of poor economic output [4-6]. It is the third most important cause of economic loss after reproduction and mastitis [7], and one of the most serious threats to the well-being of dairy cows [8], because it is associated with painful conditions in the locomotory apparatus $[7,9,10]$. It is a clinical sign with a multifactorial etiology involving infectious, noninfectious, and traumatic injuries [11-13]. Several studies have reported associations between lameness and factors at the herd level such as aspects of housing and flooring [9,14,15], management [16], food and environmental conditions [17], access to pasture, and footbath frequency [18], as well as individual factors such as breed [9,15], parity, and stage of lactation [19], and body condition [8]. These variables contribute to the variation in the lameness of dairy cows [20]. The prevalence of lameness has been assessed in the previous studies and is considered unacceptably high; moreover, the range of lesions that appear is wide and diverse [21]. It is, therefore, crucial for dairy farmers, for the sake of animal health and economy, to control the condition of the feet of their entire herd. The implementation of control measures requires knowledge of the prevalence of lameness and its associated risk factors. Its evaluation is useful also to veterinarians, researchers, and those involved in animal welfare verification programs in their efforts to reduce lameness [22]. To estimate this prevalence, visual observation of gait and posture abnormalities remains the most common method that facilitates earlier identification, quantification, and treatment of lameness lesions [16,22,23].

Despite the above-mentioned research in many countries all over the world, the lameness of Algerian dairy cows has not been sufficiently researched. Although its prevalence has so far been reported by only one other recently published study [24], specific information about risk factors for lameness in Algeria has never been researched before. Thus, our aim was to investigate the risk factors related to environmental conditions, housing, management, and facility design associated with lameness lesions in dairy cows, raised in small Algerian farms, in the northeastern region of the country.

\section{Materials and Methods}

\section{Ethical approval}

This study does not require the approval of the Animal Ethics Committee of the University of Chadli Bendjedid El Tarf, Algeria. No procedures performed in the study affected the animals.

\section{Study areas}

The study was carried out on 14 farms in three provinces of the far Northeast of Algeria. Annaba and El-Tarf (areas I and II) are located on the coastal strip and are subject to a Mediterranean climate, experiencing mild and humid weather in winter and hot and dry weather in summer. The average annual rainfall ranges between 400 and $1000 \mathrm{~mm}$, and the average annual temperature is $18^{\circ} \mathrm{C}[25,26]$. At an altitude of approximately $290 \mathrm{~m}$, the Guelma region (area III) is located in the interior of the country and is subject to a harsh climate that alternates between cold and wet winters to hot and dry summers. The annual average rainfall and temperature is $400-500 \mathrm{~mm}$ in the south to nearly $1000 \mathrm{~mm} /$ year in the north, and $17^{\circ} \mathrm{C}$, respectively [26].

\section{Study design and population}

This cross-sectional study included 349 cows from 14 small-scale farms and located in three regions: One farm in region I (Annaba), 11 in region II (El-Tarf), and two in region III (Guelma). A list of farms was previously provided by the Algerian Directorate of Agricultural Services and Fisheries Assistance. All animals of each selected farm were included in the study. Farmers and their veterinarians agreed to participate. No farms were excluded from the study, but animals were excluded from the study for some analyses when data were not available. The cows were managed in two groups: The Holstein cows' group (highly concentrated feed) and Brown Atlas cows' group (low concentrated feed and free community pastures outside all year round). One farm $(n=65$ Holsteins) followed a zero-grazing feeding system (intensive), three farms $(n=128$ Holsteins) grazed their cows in spring (semi-intensive), and ten farms $(n=156$ Brown Atlas cows) grazed their cows at free communal pastures all year round (extensive). The farms were classified into two categories: Small $(\leq 30)$ and large (>30 cows). Nine farms (216 cows) were housed in tie stalls (TS) and five (133 cows) were housed in free stalls (FS). Of the nine TS farms, three (housing 142 Holsteins) had concrete grating flooring with straw bedding, and six (housing 74 Brown Atlas cows) used wood chips bedding over the dirt floor. With regard to the five FS farms, four (housing 82 
Brown Atlas cows) used wood chips bedding over the dirt floor while one (housing 51 Holsteins) used sand as stall bases. Cows were also grouped based on the first parity, second parity, and third parity and above. With regard to claw health management practices, four farms had a claw trimming program and three used a footbath (Table-1).

\section{Data collection}

Due to practical reasons and availability of students, farms were visited from December 2012 to May 2013 in region I, December 2013 to May 2014 in region II, and December 2014 to May 2015 in region III. Each farm from each region was visited twice monthly for 6 months. All data were collected by the same two trained observers from the University of Chadli Bendjedid, Department of Veterinary Medicine, in El-Tarf. They are helped by two students during this visit. Farmers received a questionnaire to be completed the same day. Using farm records, the following data were collected for each cow and farm during initial farm visits: Calving date, herd size, cattle breed, age of livestock, housing, flooring, management, nutrition, cleanliness of the herd, and frequency of footbath, and claw trimming. During the monitoring visits, all changes in the condition of the cattle and their environment after the first visit were recorded. The effect of milk production was not taken into account in this study, as precise information on monthly milk production was not available for Brown Atlas cows.

\section{Diagnosis of lameness lesions}

To minimize the potential for between observer bias, all assessors $(n=4)$ underwent a training session for lameness scoring before the start of the study, and assessment of locomotion, by an experienced locomotion scorer. Cases of lameness were observed and recorded by farm staff and confirmed by the veterinarian of the same herd and the two authors. We chose the DairyCo mobility score, suggested by Barker et al.[27], for its ease of use and to allow for rapid training of assessors, as the rating is based on animal locomotion alone, and is designed for practical use on the farm. The same two trained observers performed the locomotion scoring on all farms, using a four-point scoring scale, where $0=$ sound locomotion, $1=$ imperfect locomotion, $2=$ lame, and $3=$ severely lame, as shown in Table-2. Holstein cows were observed when they leave the milking parlor or an outdoor exercise area. In the case of Brown Atlas cows, scores were obtained by observing them in the pasture. Cows were defined as lame if limping was present, when walking, which was equivalent to a score of $\geq 2$ on at least one of all visits. Cows without lameness were classified as healthy. At trimming, foot disorders in the lame cows were diagnosed, and they were treated in accordance with the "Dutch trimming method" [28]. The reports on foot disorders were written jointly by the veterinary practitioner and the two authors. We used a reference sheet with illustrations and descriptions of the different levels of foot lesions to assist in the recognition of lesions according to the Merck veterinary manual [29]. Only the presence or absence of lesions, without the notion of severity or gravity, was taken into account. Depending on the location of the different claw areas described by Greenough and Vermunt [30], two categories of lesions were recorded: Lameness lesions in the skin and interdigital space and in-claw lesions. Heel horn erosion (HE), which is considered a secondary complication to interdigital dermatitis (ID) [31-33], interdigital phlegmon (IP), and digital dermatitis (DD) are the most common infectious lesions of the skin and interdigital space [34]. Laminitis-related lesions are the most common non-infectious lesions of the claw. Hoof overgrowth, subacute laminitis, or chronic laminitis were coded "L." Stones and foreign bodies embedded in the foot as well as an injury in the sole and interdigital space were coded as traumas " $\mathrm{T}$ " [11].

\section{Statistical analysis}

The prevalence of lame lesions was computed by dividing the total number of cows observed with a locomotion score $\geq 2$ by the total number of cows. Pearson's Chi-square test was used to compare the prevalence of lameness in the univariable analysis. An association was considered significant at the level of $\mathrm{p}<0.05$. The statistical analyses of data were performed using R Version 3.3.3. [35].

\section{Results}

\section{Prevalence of lame lesions}

The descriptive results of the prevalence of lame lesions and associated risk factors are summarized in Tables- 1 and 3. The overall prevalence of lame lesions was $13 \%$ (lameness score $\geq 2$ ), across the 14 farms, and the within-regions prevalence scores were $15.6 \%$, $11.3 \%$, and $17 \%$ in Annaba, El-Tarf, and Guelma, respectively. In the cows, $24 \%$ of lameness lesions were in the forefeet and $76 \%$ were in the hind feet. All affected cows were lame only in one foot. Infectious lameness lesions, including ID/HE, IP, and DD, were recorded in $82.6 \%$ of lame cows, and non-infectious lameness lesions, including $\mathrm{L}$ and $\mathrm{T}$, were recorded in $17.4 \%$ of lame cows. This difference was statistically significant $(p=0.002)$. ID/HE and IP were the most frequently diagnosed diseases as causes of lameness, accounting for $39 \%$ and $34.9 \%$ of the total, respectively, followed by $\mathrm{T}(11 \%)$, DD $(8.7 \%)$, and L (6.5\%). Statistically significant differences were observed between the prevalence rates of lame lesions $(\mathrm{p}<0.001)$.

\section{Risk factors analysis}

The percentage of lame lesions at the cow and farm-level factors is reported in Table- 1 and its significance in Table-3. Two individual factors increased the risk of lame: The Holstein cows (22.8 vs. $1.3 \%$ for Brown Atlas cows), and third parity or above (16.2 vs. 
Table-1: Distribution of farm and cow-level factors between cows with lame lesions among 14 Algerian small-scale dairy farms and 349 cows included in the analysis (2012-2015).

\begin{tabular}{|c|c|c|c|}
\hline \multirow[t]{2}{*}{ Risk factors } & \multirow[t]{2}{*}{ All cows $(n=349)$} & \multirow[t]{2}{*}{ Farms $(n=14)$} & \multirow{2}{*}{$\begin{array}{c}\text { Lame cows } \\
\text { Number }(\%)\end{array}$} \\
\hline & & & \\
\hline \multicolumn{4}{|l|}{ Region } \\
\hline Annaba (I) & 51 & 1 & $8(15.6)$ \\
\hline El Tarf (II) & 221 & 11 & $25(11.3)$ \\
\hline Guelma (III) & 77 & 2 & $13(16.8)$ \\
\hline \multicolumn{4}{|l|}{ Breed } \\
\hline Holstein & 193 & 4 & $44(22.8)$ \\
\hline Brown of atlas & 156 & 10 & $2(1.3)$ \\
\hline \multicolumn{4}{|l|}{ Herd size (number of animals) } \\
\hline$\geq 10$ & 29 & 3 & $0(0.00)$ \\
\hline $11-30$ & 141 & 8 & $4(2.8)$ \\
\hline$>30$ & 179 & 3 & $42(23.4)$ \\
\hline \multicolumn{4}{|l|}{ Season } \\
\hline Winter & 349 & 14 & $34(74)$ \\
\hline Spring & 349 & 14 & $12(26)$ \\
\hline \multicolumn{4}{|l|}{ Housing system } \\
\hline Tie-stalls & 216 & 9 & $38(17.6)$ \\
\hline Free-stalls & 133 & 5 & $8(6.01)$ \\
\hline \multicolumn{4}{|l|}{ Flooring system } \\
\hline Solid concrete & 142 & 3 & $36(25.35)$ \\
\hline Earthen floor & 156 & 10 & $2(1.3)$ \\
\hline Sand & 51 & 1 & $8(15.7)$ \\
\hline \multicolumn{4}{|l|}{ Feeding } \\
\hline Highly concentrated feed & 193 & 4 & $44(22.8)$ \\
\hline Low concentrated feed & 156 & 10 & $2(1.3)$ \\
\hline \multicolumn{4}{|l|}{ Grazing } \\
\hline Grazing period & 128 & 3 & $21(16.4)$ \\
\hline Zero-grazing & 65 & 1 & $23(35.4)$ \\
\hline Pasture all years & 156 & 10 & $2(1.3)$ \\
\hline \multicolumn{4}{|l|}{ Parity } \\
\hline $1^{\text {st }}$ parity & 76 & 14 & $3(3.9)$ \\
\hline $2^{\text {nd }}$ parity & 82 & 14 & $12(14.6)$ \\
\hline$\geq 3^{\text {rd }}$ parity & 191 & 14 & $31(16.2)$ \\
\hline \multicolumn{4}{|l|}{ Presence of a footbath } \\
\hline Yes & 128 & 3 & $21(16.4)$ \\
\hline No & 221 & 11 & $25(11.31)$ \\
\hline \multicolumn{4}{|l|}{ Periodical foot trimming } \\
\hline Once a year & 128 & 3 & $21(16.4)$ \\
\hline Occasionally & 65 & 1 & $23(35.4)$ \\
\hline Not at all & 156 & 10 & $2(1.3)$ \\
\hline \multicolumn{4}{|l|}{ Lame lesions } \\
\hline $\mathrm{ID} / \mathrm{HE}$ & $18(39)$ & 3 & $18(39)$ \\
\hline IP & $16(35)$ & 4 & $16(35)$ \\
\hline DD & $4(8.7)$ & 2 & $4(8.7)$ \\
\hline L & $3(6.5)$ & 2 & $3(6.5)$ \\
\hline $\mathrm{T}$ & $5(11)$ & 3 & $5(11)$ \\
\hline All diagnoses & $46(13.2)$ & & $46(13.2)$ \\
\hline \multicolumn{4}{|l|}{ Limb affected } \\
\hline Fore limb & $11(24)$ & & $11(24)$ \\
\hline Hind limb & $35(76)$ & & $35(76)$ \\
\hline
\end{tabular}

ID/HE=Interdigital dermatitis/heel horn erosion, IP=Interdigital phlegmon, DD=Digital dermatitis, $\mathrm{L}=$ Laminitis-related diseases, $T=$ Traumatic lesions

Table-2: Lameness scoring scale dairy Co-adapted by Barker et al. [27].

\begin{tabular}{ll}
\hline Mobility score & Criteria \\
\hline 0 & Sound/Perfect gait \\
1 & Abnormal locomotion, but not favoring \\
& any particular limb/tender-footed gait \\
2 & Lame and uneven or arched back \\
3 & $\begin{array}{l}\text { Severely lame with score "2" conditions } \\
\text { and a very slow gait. Slower than the } \\
\text { pace of "brisk walk" by a human }\end{array}$ \\
\hline
\end{tabular}

$3.9 \%$ in $1^{\text {st }}$ parity). At the farm level, the prevalence of lame lesions was significantly associated with cows reared under zero-grazing (35.4\%) compared to grazing period $(16.4 \%)$ and pasture all year $(1.3 \%)$, and cows kept in tie housing (17.6\%) compared to free-housing $(6.01 \%)$, and those with concrete floor $(25.3 \%)$ in comparison to sand $(15.7 \%)$ or dirt stall bases $(1.3 \%)$, winter housing (74 vs. $26 \%$ in spring), and concentrate feeding ( 22.8 vs. $1.3 \%$ for low concentrated feed). In addition, the risk for the lame 
Table-3: The variables tested in the univariable analysis for association with lame lesions in 14 Algerian smallscale dairy farms and 349 cows (2012-2015).

\begin{tabular}{|c|c|c|c|}
\hline Risk factors & $\chi^{2 \mathrm{a}}$ & df & p-value \\
\hline \multicolumn{4}{|l|}{ Region } \\
\hline Annaba (I) & 1.87643 & 2 & $p=0.39$ \\
\hline \multicolumn{4}{|l|}{ El Tarf (II) } \\
\hline \multirow{2}{*}{\multicolumn{4}{|c|}{$\begin{array}{l}\text { Guelma (III) } \\
\text { Breed }\end{array}$}} \\
\hline & & & \\
\hline Holstein & 17.7144 & 1 & $\mathrm{p}<0.001$ \\
\hline \multicolumn{4}{|l|}{ Brown of atlas } \\
\hline \multicolumn{4}{|l|}{ Herd size (number of animals) } \\
\hline$\leq 10$ & 41.7798 & 2 & $\mathrm{p}<0.001$ \\
\hline \multicolumn{4}{|l|}{$11-30$} \\
\hline \multicolumn{4}{|l|}{$>30$} \\
\hline \multicolumn{4}{|l|}{ Husbandry system } \\
\hline Intensive & 34.9000 & 1 & $\mathrm{p}<0.001$ \\
\hline \multicolumn{4}{|l|}{ Extensive } \\
\hline \multicolumn{4}{|l|}{ Season } \\
\hline Winter & 11.6419 & 2 & $p=0.003$ \\
\hline \multicolumn{4}{|l|}{ Spring } \\
\hline \multicolumn{4}{|l|}{ Housing system } \\
\hline Tie stalls & 9.64193 & 1 & $p=0.002$ \\
\hline \multicolumn{4}{|l|}{ Free-stalls } \\
\hline \multicolumn{4}{|l|}{ Flooring system } \\
\hline \multirow{2}{*}{\multicolumn{4}{|c|}{ Earth floor }} \\
\hline & & & \\
\hline \multicolumn{4}{|l|}{ Sand } \\
\hline \multicolumn{4}{|l|}{ Feeding } \\
\hline Highly concentrated feed & 34.9000 & 1 & $P<0.001$ \\
\hline Low concentrated feed & & & \\
\hline \multicolumn{4}{|l|}{ Parity } \\
\hline $1^{\text {st }}$ parity & 22.7839 & 2 & $\mathrm{p}<0.001$ \\
\hline \multicolumn{4}{|l|}{$2^{\text {nd }}$ parity } \\
\hline \multicolumn{4}{|l|}{$\geq 3^{\text {rd }}$ parity } \\
\hline \multicolumn{4}{|l|}{ Periodical trimming } \\
\hline Once a year & 48.4685 & 2 & $p<0.001$ \\
\hline \multicolumn{4}{|l|}{ Occasionally } \\
\hline \multicolumn{4}{|l|}{ Not at all } \\
\hline Footbaths & & & \\
\hline Yes & 1.83802 & 1 & $p=0.18$ \\
\hline No & & & \\
\hline Lameness & & & \\
\hline HH/ID & 22.478 & 4 & $p<0.001$ \\
\hline IP & & & \\
\hline DD & & & \\
\hline L & & & \\
\hline $\mathrm{T}$ & & & \\
\hline All diagnoses & & & \\
\hline Foot lame lesions & & & \\
\hline IFL: Infectious foot lesions & 10.9466 & 1 & $p=0.002$ \\
\hline NIFL: Non-infectious foot lesions & & & \\
\hline
\end{tabular}

aChi-square Pearson's test, $\mathrm{df}=$ Degrees of freedom,

IFL=Infectious foot lesions, NIFL=Non-infectious foot lesions

lesions was higher in large herds $>30$ cows and those that used a foot trimming occasionally $(35.4 \%)$ compared to those that did regularly $(16.4 \%)$. However, on pasture all year, the lowest rate is recorded when cows have not been trimmed at all $(1.3 \%)$. Non-significant $(p \geq 0.05)$ association between the prevalence of lame lesions and the region and footbath was observed.

\section{Discussion}

Few published articles report on the prevalence of epidemiological lameness cows in regions outside the United States, the Netherlands, and the European countries [36]. A noted strength of our work is that this is the first published study which has provided information on the environmental, management, and facility practices risk factors associated with lame lesions in Algerian dairy cattle. This data should provide a reference point for comparison with data from other countries. We and managers have more opportunities to observe each individual cow as she walks in order to detect lameness because most of the smallholder dairy cattle are family managed and are easy to manage due to proximity of the animals. However, several negative factors for animal welfare and milk production are mentioned earlier [3], cattle diseases are also common, especially the high prevalence of parasitic, including tick-borne diseases [37], particularly in herds that graze, whose exposure to ticks is greater. Anaplasmosis and piroplasmosis are also prevalent, especially in low land humid areas [38]. We also encountered several problems associated with the collection and access to registered data on past farming practices, herd management, and performance that is lacking for most extensive farms. The presence of other livestock species, such as dogs, sheep, and poultry is also frequent.

Several limitations exist in this study that should be addressed with future research. First, our data come from small herds; hence, this study population cannot be considered representative of Algerian dairy herds in general. Second, lameness cannot necessarily be identified and recorded in a comparable way $[6,23,39]$. Third, several specific combinations of risk factors have been associated with an increased prevalence of lame cows, and it has been difficult to conduct a comparison with the results of other studies and countries $[9,23]$. In addition, the previous research has shown that inter-rater reliability for locomotion scoring can be variable [6]. Here, interobserver reliability for lameness scoring was not assessed. However, we believe that the implemented training session, the same two trained observers, the simplest gait score, and his frequent use, the small herd size, and periodic visits throughout the study; collectively, these contributed to the achievement of high interobserver agreement. The effect of milk production and the weight of the cow that were not taken into account in this study, as precise information on monthly milk production, were not available for Brown Atlas cows, as detailed and representative information are difficult to collect. Hence, these factors might explain these differences in risk of lameness between Holstein and the Brown Atlas cows.

Data on the overall prevalence of lameness (13\%) support the only Algerian study (12.7\%) [24] and are consistent with those presented in related studies from Kenya (11.7\%) [40], Spain (13.8\%)[41], Switzerland (14.8\%) [42], Australia (18.9\%) [17], some other European countries (18\%) [39], and Malaysia (19\%)[43]. However, the estimate of lameness prevalence in this study was lower than that of farms in the Northeastern United States (55\%) [44], England 
and Wales (37\%) [27], Canada (36\%) [13], Brazil (35\%) [45], Austrian and German (34\%) [9], and China (31\%) [18]. Accordingly, Green et al. [46] indicate that the prevalence of lameness in dairy cows is high in developed countries. However, recent studies in North America have reported a lower prevalence of $13.2 \%$ [47] and $7.2 \%$ [14]. This high variability in lameness estimates is reported worldwide. Some of the variations can be attributed to the difficulty in defining clinical lameness in dairy cows [5], as well as the difference in lameness scoring system used, and interobserver reliability for lameness scoring [6]. Part of the variation may also be attributed to the different skills of personnel responsible for identifying lame cows, in sample size, climate, and disease status of infectious claw diseases, breed selection, and productivity of the cows $[15,46]$. On the other hand, infectious causes of lameness were predominant in this study, accounting for $82.6 \%$ of all diagnoses. Among the lame infectious lesions recorded, ID/HE and IP were the most common causes of lameness, DD was reported less commonly. Somers et al. [34], Frankena et al. [48], and Refaai et al. [33] obtained similar results for associations between lameness and infectious lesions such as ID/HE and DD in their studies. Possible reasons for the high prevalence of infectious lesions are the unhygienic environmental conditions, such as the accumulation of manure, feces, and urine, which are considered important predisposing factors [34]. These diseases are highly transmissible, especially when floors are not properly cleaned [49], as was the case in this study.

Several risk factors were associated with the prevalence of lame in this study. In terms of the breed effect, Holstein cows had the highest risk of lame lesions than did Brown Atlas cows. Our results are consistent with several studies comparing jersey [20,22,45], crossbreeds [27], Ayrshire [15], and other breeds [17,39] to Holstein cows. The reason for this could be that lameness has been indicated as a major problem in Holstein herds [27]. In addition, Holsteins are on average bigger and have higher milk yield, which can be associated with more concentrated feeding [15] that, in turn, could predispose them directly or indirectly to lameness problems $[20,50]$. On the other hand, the composition of breeds varied considerably from country to country, with some breeds being very country-specific [39]. The Brown Atlas is a light and thin cow, permanently housed in pastures and fed a low-carbohydrate, and high-fiber diet.

Lame lesions prevalence increased with increasing parity. This is partly in agreement with several studies which found more lameness with increasing age $[9,45]$. This association may be explained by the fact that older cows are predisposed to relapse with certain foot lesions and are exposed for longer intervals to the housing environment than are younger cows $[6,15]$.

The prevalence of lameness, and the lesions associated with the lameness, varies widely between different management systems; this prevalence is high in the farms of the intensive and semi-intensive system, in which cows produced more milk, received a large proportion of their feed as silage and grains, and spent a large proportion of the day indoors [51]. From experiences in practice, it has been suggested that the prevalence of lameness is higher when cattle stay indoors all year round $[17,40,50]$. However, the lower levels of lameness in an extensive farming system may have been a result of the high use of pasture and the use of genotypes adapted to the environment, and low levels of supplementation and lower milk production; similar results have been observed elsewhere [42,51]. Access to pasture is known to be beneficial for foot health; it reduces the risk of lameness by providing a large housing surface, beneficial claw wear, good traction, and low levels of fecal bacteria $[39,52]$. The risk factors for lameness in the pasture are related to the risk of trauma, for example, from long walking distances and lack of track maintenance [51], as was the case in this study.

Several studies $[9,14,15]$ have estimated the prevalence of lameness lesions in dairy cattle and some have shown associations between housing and lameness. It has been frequently reported that FS housing increases the incidence of lameness compared to tie housing $[12,13,23]$. However, in our sample, we observed a higher prevalence of cows with lame lesions confined in TS. We revealed that FS with sand or dirt bases were associated with a lower prevalence of lameness in cows than were solid flooring TS. This finding can be attributed to the type of stall base, which is more important than the type of housing system. Studies $[4,18]$ found a higher prevalence of lameness in FS than in TS but not when FS with sand as the stall base were compared with non-sand TS. Faye and Lescouret [53] reported fewer cases of lameness in farms with dirt stall bases than in farms with concrete stall bases, which can be attributed to the fact that the ground is soft, flexible, and nonabrasive, and ultimately reduces the risk of lameness. The use of solid concrete bedding can affect digital health, as continuously wet, irregularly scraped, and insufficiently mulched conditions favor infectious diseases [54], as was the case in this study. The hardness, abrasiveness, and slipperiness of such stall bases have adverse effects on animal welfare and health $[12,19]$.

In general, the larger the herd size, the greater the risk of lameness. In accordance with this observation, some studies $[22,55]$ found that in a large herd, more procedures are mechanized than in a small herd. A high degree of mechanization can reduce the time the farmer spends with each cow, which could be associated with a higher frequency of lameness [20]. Diets with a high concentrate to roughage ratio have traditionally been considered as one of the major risk factors for lameness [19]. This diet is one of the primary underlying causes of laminitis [17], particularly the consumption of high-concentrate diets, which are 
more common in Holstein than in Brown Atlas cows in this study. Furthermore, dairy cows with high genetic potential for milk yield have been shown to have an increased risk of lameness. Other factors associated with nutrition, such as frequency of feeding and feed composition [39], may be of greater importance in terms of lameness, but these were not investigated.

This study also revealed that farms that trimmed claws of cattle at decreased frequencies (occasionally) had an increased prevalence of lame cows than did those that routinely trimmed claws of cattle. Results from prior studies $[34,41,53]$ have shown that long intervals between claw trimmings are associated with increased lameness. Studies have also revealed that farms where cattle's claws are trimmed only when they are overgrown or when lameness has occurred have higher levels of lameness [56]. However, with regard to cows raised on pastures, we show that the lowest rate of lameness is recorded when their claws have not been trimmed at all. Here, when cattle graze in pastures all year round and walk long distances every day on gravel or concrete, claw trimming is rarely necessary. Claw trimming has many proved positive effects that aim to restore finger health and improve animal welfare, as other studies report [19,34,43], but it is not the only way to prevent lameness, because possible lameness problems caused by the trimming process have also been reported. It was not possible to assess the quality of claw trimming, and it is likely that incorrect trimming techniques could worsen the problem. In general, poor-quality trimming has been recognized as a factor contributing to the occurrence of locomotion disorders, exposing the feet to all kinds of injuries and pathogen penetration [57]. Excessive hoof wear and tear can cause instability on concrete thus creating pain and discomfort for the cow, leading to a higher probability of recurrence of lame lesions [42].

Footbath was not a general practice in most of the studied farms; only three farms were using the footbath on a regular basis. The routine use of a footbath was associated with a greater prevalence of lameness in cows, as other studies have also reported $[11,27,58]$. Although, many studies have shown that routine footbathing is associated with a lower prevalence of lameness $[55,59]$. In this study, only the presence or absence of a footbath is taken into account; the design, protocols of footbaths, and choice of disinfectants vary considerably $[31,59]$; however, their effects on lameness were not estimated. For disinfectants, copper sulfate, Javel water, and Cresyl solutions (5\%) were the most commonly used materials in our footbath systems. These materials are very disadvantageous for the environment [31], as they deteriorate rapidly in the presence of a very high amount of organic matter. This phenomenon makes them unsuitable for use in footbaths. Considering the factors of race, grazing and housing, considering the disinfectants used, it is believed that our results are very much due to improper use of footbath instead. The presence of a foot bath has to be seen as an effect of higher lameness prevalence rather than as a cause. The benefit of the use of footbathing under our conditions is less clear and further research is required.

\section{Conclusion}

Any measures aimed to reduce the prevalence of lameness should be geared toward minimizing the constraints experienced by the smallholder dairy farmers. The identification, treatment, and prevention of lameness are a challenge to dairy farmers, with the causes being multifactorial and involving factors such as nutrition, management practices, housing, and environmental conditions. In confinement, cattle need to be provided with amble comfort by providing good housing and environmental conditions. Deep bedding (sand or dirt bases) provides the best comfort and contributes the least to lameness. For cattle with infectious lesions, control will need to aim at the hygiene of the floors, stalls, and foot. It is essential to provide feeding strategy of cattle living under the extensive system since the pasture forage has lower nutritional value. Farmers in the study area should be encouraged to use locomotion scoring tool to identify lame cows. The benefit of routine claw trimming and the use of footbathing under our conditions are less clear and further research is required.

\section{Authors' Contributions}

$\mathrm{ZD}, \mathrm{LD}$, and FZ participated in the conceptual aspect and design of the study, collected the data, and prepared the manuscript. KS and FS contributed to analyzing data. $\mathrm{AB}$ revised and corrected the manuscript. All authors read and approved the final version of the manuscript.

\section{Acknowledgments}

The authors did not receive any funding for this study. The authors would like to thank farmers, veterinarians, and technicians for their help and support during the field study. We also acknowledge the support of the Algerian Direction of Agricultural Services.

\section{Competing Interests}

The authors declare that they have no competing interests.

\section{Publisher's Note}

Veterinary World remains neutral with regard to jurisdictional claims in published institutional affiliation.

\section{References}

1. Kaouche-Adjlane, S., Ghozlane, F. and Mati, A. (2015) Typology of dairy farming systems in the Mediterranean basin (Case of Algeria). Biotechnol. Anim. Husbandry, 31(1): 385-396.

2. MADR. (2013) Statistiques agricoles: superficies et productions. Ministère de l'Agriculture et du développement rural. Série A et B, Algérie. 
3. Srairi, M.T., Benyoucef, M.T. and Kraiem, K. (2013) The dairy chains in North Africa (Algeria, Morocco and Tunisia): From self sufficiency options to food dependency? Springer Plus, 162(2): 1-13.

4. Espejo, L.A., Endres, M.I. and Salfer, J.A. (2006) Prevalence of lameness in highproducing Holstein cows housed in freestall Barns in Minnesota. J. Dairy Sci., 89(8): 3052-3058.

5. Green, L.E., Hedges, V.J., Schukken, Y.H., Blowey, R.W. and Packington, A.J. (2002) The impact of clinical lameness on the milk yield of dairy cows. J. Dairy Sci., 85(9): 2250-2256.

6. Solano, L., Barkema, H.W., Pajor, E.A., Mason, S., LeBlanc, S.J., Heyerhoff, J.C.Z., Nash, C.G.R., Haley, D.B., Vasseur, E., Pellerin, D., Rushen, J., de Passillé, A.M. and Orsel, K. (2015) Prevalence of lameness and associated risk factors in Canadian Holstein-Friesian cows housed in freestall barns. J. Dairy Sci., 98(10): 6978-6991.

7. Van Nuffel, A., Zwertvaegher, I., VanWeyenberg, S., Pastell, M., Thorup, V.M., Bahr, C., Sonck, B. and Saeys, W. (2015) Lameness detection in dairy cows: Part 1. How to distinguish between non-lame and lame cows based on differences in locomotion or behavior. Animals, 5(3): 838-860.

8. Green, L.E., Huxley, J.N., Banks, C. and Green, M.J. (2014) Temporal associations between low body condition, lameness and milk yield in a UK dairy herd. Prev. Vet. Med., 113(1): 63-71.

9. Dippel, S., Dolezal, M., Brenninkmeyer, C., Brinkmann, J., March, S., Knierim, U. and Winckler, C. (2009) Risk factors for lameness in freestall-housed dairy cows across two breeds, farming systems, and countries. J. Dairy Sci., 92(11): 5476-5486.

10. Nechanitzky, K., Starke, A., Vidondo, B., Muller, H., Reckardt, M., Friedli, K. and Steiner, A. (2016) Analysis of behavioral changes dairy cows associated with claw horn lesions. J. Dairy Sci., 99(4): 2904-2914.

11. Amory, J.R., Barker, Z.E.,Wright, J.L., Mason, S.A., Blowey, R.W. and Green, L.E. (2008) Associations between sole ulcer, white line disease and digital dermatitis and the milk yield of 1824 dairy cows on 30 dairy cow farms in England and Wales from February 2003 November 2004. Prev. Vet. Med., 83(3-4): 381-391.

12. Fjeldaas, T., Sogstad, Å.M. and Østerås, O. (2011) Locomotion and claw disorders in Norwegian dairy cows housed in free stalls with slatted concrete, solid concrete or solid rubber flooring in the alleys. J. Dairy Sci., 94(3): 1243-1255.

13. Solano, L., Barkema, H.W., Mason, S., Pajor, E.A., LeBlanc, S.J. and Orsel, K. (2016) Prevalence and distribution of foot lesions in dairy cattle in Alberta, Canada. $J$. Dairy Sci., 99(8): 6828-6841.

14. Adams, A.E., Lombard, J.E., Fossler, C.P., RománMuñiz, I.N. and Kopral, C.A. (2017) Associations between housing and management practices and the prevalence of lameness, hock lesions, and thin cows on US dairy operations. J. Dairy Sci., 100(3): 2119-2136.

15. Sarjokari, K., Kaustell, K.O., Hurme, T., Kivinen, T., Peltoniemi, O.A.T., Saloniemi, H. and Rajala-Schultz, P.J. (2013) Prevalence and risk factors for lameness in insulated free stall barns in Finland. Livest. Sci., 156(1-3): 44-52.

16. Shearer, J.K., Stock, M.L., Van Amstel, S.R. and Coetzee, J.F. (2013) Assessment and management of pain associated with lameness in cattle Lameness locomotion scoring systems. Vet. Clin. North Am. Food Anim. Pract., 29(1): 135-156.

17. Ranjbar, S., Rabiee, A.R., Gunn, A. and House, J.K. (2016) Identifying risk factors associated with lameness in pasture-based dairy herds. J. Dairy Sci., 99(9): 7495-7505.

18. Chapinal, N., Liang, Y., Weary, D.M., Wang, Y. and von Keyserlingk, M.A.G. (2014) Risk factors for lameness and hock injuries in Holstein herds in China. J. Dairy Sci., 97(7): 4309-4316.
19. Sogstad, A.M., Fjeldaas, T. and Osteras, O. (2005) Lameness and claw lesions of the Norwegian red dairy cattle housed in free stalls in relation to environment, parity and stage of lactation. Acta Vet. Scand., 46(4): 203-217.

20. Alban, L. (1995) Lameness in Danish dairy cows: Frequency and possible risk factors. Prev. Vet. Med., 22(3): 213-225.

21. Potterton, S.L., Bell, N.J., Whay, H.R., Berry, E.A., Atkinson, O.C.D., Dean, R.S., Main, D.C.J. and Huxley, J.N. (2012) A descriptive review of the peer and non-peer reviewed literature on the treatment and prevention of foot lameness in cattle published between 2000 and 2011. Vet. J., 193(3): 612-616.

22. Hoffman, A.C., Moore, D.A., Wenz, J.R. and Vanegas, J. (2013) Comparison of modeled sampling strategies for estimation of dairy herd lameness prevalence and cow-level variables associated with lameness. J. Dairy Sci., 96(9): 5746-5755.

23. Cramer, G., Lissemore, K.D., Guard, C.L., Leslie, K.E. and Kelton, D.F. (2008) Herd-and cow-level prevalence of foot lesions in Ontario dairy cattle. J. Dairy Sci., 91(10): 3888-3895.

24. Ouared, K., Zidane, H., Aggad, A. and Niar, A. (2015) Impact of clinical lameness on the milk yield of dairy cows. J. Anim. Vet. Adv., 14(1): 10-12.

25. Adel, A., Boughoufalah, A. and Saegerman, C. (2014) Epidemiology of visceral leishmaniasis in Algeria: An update. PLoS One, 9(6): e99207.

26. Meguini, M.N., Righi, S., Zeroual, F., Saidani, K. and Benakhla, A. (2018) Inventory of lice of mammals and farmyard chicken in North-Eastern Algeria. Vet. World, 11(3): 386-396.

27. Barker, Z.E., Leach, K.A., Whay, H.R., Bell, N.J. and Main, D.C.J. (2010) Assessment of lameness prevalence and associated risk factors in dairy herds in England and Wales. J. Dairy Sci., 93(3): 932-941.

28. Toussaint-Raven, E. (1985) Cattle Footcare and Claw Trimming. Farming Press, Ipswich, UK.

29. The Merck Veterinary Manual. Lameness in Cattle. Available from: http://www.merckvetmanual.com/mvm/ musculoskeletal_system/lameness_in_cattle/overview_of lameness in_cattle. Retrieved on $0 \overline{3}-0 \overline{7}-2014$.

30. Greenough, P.R. and Vermunt, J.J. (1991) Evaluation of subclinical laminitis in a dairy herd and observations on associated nutritional and management factors. Vet. Rec., 128(1): 11-17.

31. Fjeldaas, T., Knappe-Poindecker, M., Bøe, K.E. and Larssen, R.B. (2014) Water footbath, automatic flushing, and disinfection to improve the health of bovine feet. $J$. Dairy Sci., 97(5): 2835-2846.

32. Greenough, P.R. (2007) Bovine Laminitis and Lameness a Hands-on Approach. Elsevier, Saunders, Philadelphia, PA.

33. Refaai, W., Van Aert, M., Abd El-Aal, A.M., Behery, A.E. and Opsomer, G. (2013) Infectious diseases causing lameness in cattle with the main emphasis on digital dermatitis (digital dermatitis disease). Livest. Sci., 15(1-3): 53-63.

34. Somers, J.G.C., Frankena, J.K., Noordhuizen-Stassen, E.N. and Metz, J.H.M. (2005b) Risk factors for interdigital dermatitis and heel erosions in dairy cows kept in cubicle houses in the Netherlands. Prev. Vet. Med., 71(1-2): 23-34.

35. R Core Team. (2016) A Language and Environment for Statistical Computing. R Foundation for Statistical Computing, Vienna, Austria. Available from: http:// www.R-project.org. Retrieved on 24-02-2016.

36. Costa, J.H., Burnett, T.A., von Keyserlingk, M.A. and Hötzel, M.J. (2018) Prevalence of lameness and leg lesions of lactating dairy cows housed in southern Brazil: Effects of housing systems. J. Dairy Sci., 101(3): 2395-2405.

37. Dib, L., Lafri, I., Boucheikhchoukh, M., Dendani, C.Z., Bitam, I. and Benakhla, A. (2019) Seasonal distribution of Rickettsia spp. in ticks in Northeast Algeria. New Microbes New Infect., 27(1): 48-52.

38. Dib, L., Bitam, I., Tahri, M., Bensouilah, M. and De 
Meeûs, T. (2008) Competitive exclusion between piroplasmosis and anaplasmosis agents within cattle. PLoS Pathog., 4(1): e7.

39. Sjöström, K., Fall, N., Blanco-Penedo, I., Duval, J.E., Krieger, M. and Emanuelson, U. (2017) Lameness prevalence and risk factors in organic dairy herds in four European countries. Livest. Sci., 208(2): 44-50.

40. Gitau, T., McDermott, J.J. and Mbiuki, S.M. (1996) Prevalence, incidence, and risk factors for lameness in dairy cattle in small-scale farms in Kikuyu Divison, Kenya. Prev. Vet. Med., 28(2): 101-115.

41. Pérez-Cabal, M.A. and Alenda, R. (2014) Clinical lameness and risk factors in a Spanish Holstein population. Livest. Sci., 164(6): 168-174.

42. Becker, J., Steiner, A., Kohler, S., Koller-Bahler, A., Wuthrich, M. and Reist, M. (2014a) Lameness and foot lesions in Swiss dairy cows: I. Prevalence. Schweiz. Arch. Tierheilkd., 156(2): 71-78.

43. Sadiq, M.B., Ramanoon, S.Z., Mansor, R., SyedHussain, S.S. and Mossadeq, W.S. (2017) Prevalence of lameness, claw lesions, and associated risk factors in dairy farms in Selangor, Malaysia. Trop. Anim Health Prod., 49(8): 1741-1748.

44. von Keyserlingk, M.A.G., Barrientos, A., Ito, K., Galo, E. and Weary, D.M. (2012) Benchmarking cow comfort on North American freestall dairies: Lameness, leg injuries, lying time, facility design, and management for high-producing Holstein dairy cows. J. Dairy Sci., 95(12): 7399-7408.

45. Bran, J.A., Daros, R.R., von Keyserlingk, M.A.G., LeBlanc, S.J. and Hötzel, M.J. (2018) Cow-and herd-level factors associated with lameness in small-scale grazing dairy herds in Brazil. Prev. Vet. Med., 151(3): 79-86.

46. Green, L.E., Borkert, J., Monti, G. and Tadich, N. (2010) Associations between lesion-specific lameness and the milk yield of 1635 dairy cows from seven herds in the $\mathrm{X}^{\text {th }}$ region of Chile and implications for the management of dairy cows worldwide. Anim. Welfare, 19(4): 419-427.

47. Cook, N.B., Hess, J.P., Foy, M.R., Bennett, T.B. and Brotzman, R.L. (2016) Management characteristics, lameness, and body injuries of dairy cattle housed in high-performance dairy herds in Wisconsin. J. Dairy Sci., 99(7): 5879-5891.
48. Frankena, K., Somers, J.G.C., Schouten, W.G.P., van Stek, J.V., Metz, J.H.M., Stassen, E.N. and Graat, E.A.M. (2009) The effect of digital lesions and floor type on locomotion score in Dutch dairy cows. Prev. Vet. Med., 88(2): 150-157.

49. Passos, L.T., da Cruz, E.A., Fischer, V., da Porciuncula, G.C., Werncke, D., Dalto, A.G.C. and da Silveira, I.D.B. (2017) Dairy cows change locomotion score and sensitivity to pain with trimming and infectious or non-infectious lesions. Trop. Anim Health Prod., 49(4): 851-856.

50. Hernandez-Mendo, O., von Keyserlingk, M.A.G., Veira, D.M. and Weary, D.M. (2007) Effects of pasture on lameness in dairy cows. J. Dairy Sci., 90(3): 1209-1214.

51. Costa, J.H.C., Hötzel, M.J., Longo, C. and Balcão, L.F. (2013) A survey of management practices that influence production and welfare of dairy cattle on family farms in Southern Brazil. J. Dairy Sci., 96(1): 307-317.

52. Olmos, G., Boyle, L., Hanlon, A., Patton, J., Murphy, J.J. and Mee, J.F. (2009) Hoof disorders, locomotion ability and lying times of cubicle-housed compared to pasture-based dairy cows. Livest. Sci., 125(2-3): 199-207.

53. Faye, B. and Lescourret, F. (1989) Environmental factors associated with lameness in dairy cattle. Prev. Vet. Med., 7(4): 267-287.

54. Wells, S.J., Trent, A.M., Marsh, W.E., McGovern, P.G. and Robinson, R.A. (1993) Individual cow risk factors for clinical lameness in lactating dairy cows. Prev. Vet. Med., 17(1-2): 95-109.

55. Katsoulos, P.D. and Christodoulopoulos, G. (2009) Prevalence of lameness and of associated claw disorders in Greek dairy cattle industry. Livest. Sci., 122(2-3): 354-358.

56. Griffiths, B.E., White, D.G. and Oikonomou, G.A. (2018) Cross-sectional study into the prevalence of dairy cattle lameness and associated herd-level risk factors in England and Wales. Front. Vet. Sci., 5(4): 65.

57. Tranter, W.P. and Morris, R.S. (1991) A case study of lameness in three dairy herds. N. Z. Vet. J., 39(3): 88-96.

58. Cook, N.B. (2017) A review of the design and management of footbaths for dairy cattle. Vet. Clin. Food Anim. Pract., 33(2): 195-225.

59. Solano, L., Barkema, H.W. and Pickel, C. (2017) Effectiveness of a standardized footbath protocol for prevention of digital dermatitis. J. Dairy Sci., 100(2): 1295-1307. 